\title{
Effect of experimental zinc deficiency and repletion on sodium, potassium, copper and iron concentrations in guinea-pigs
}

\author{
BY R. P. GUPTA ${ }^{1}$, P. C. VERMA ${ }^{1 *}$, J. R. SADANA ${ }^{1}$ AND V. K. GUPTA ${ }^{2}$ \\ ${ }^{1}$ Department of Veterinary Pathology, ${ }^{2}$ Department of Soil Science, Haryana Agricultural \\ University, Hisar-125004, India
}

(Received 30 December 1988 - Accepted 17 April 1989)

\begin{abstract}
Zinc, sodium, potassium, copper and iron concentrations were analysed in serum and tissues of guineapigs fed on a diet containing $1.25 \mathrm{mg} Z \mathrm{Zn} / \mathrm{kg}$ diet over a period of $60 \mathrm{~d}$. The response of the $\mathrm{Zn}$-deficient (ZnD) animals to $\mathrm{Zn}$ supplementation (100 $\mathrm{mg} \mathrm{Zn} / \mathrm{kg}$ diet) was also studied for $15 \mathrm{~d}$. Serum studies in the $\mathrm{ZnD}$ group revealed significant decreases in the concentrations of $\mathrm{Zn}$ and $\mathrm{Na}$ from $24 \mathrm{~d}$, and increases in the concentrations of $F e$ and $K$ from 36 and $48 \mathrm{~d}$ onwards respectively; an increase in Cu was seen on day 60 only. Zn deficiency caused significant reductions in $\mathrm{Na}, \mathrm{K}$ and $\mathrm{Zn}$ and increases in $\mathrm{Cu}$ and $\mathrm{Fe}$ contents of liver and kidney. In testis, significant decreases were noted only in $\mathrm{Zn}, \mathrm{K}$ and $\mathrm{Fe}$ contents. $\mathrm{Zn}$ supplementation of the previously $\mathrm{ZnD}$ group resulted in marked improvements in serum and tissue mineral levels. However, hepatic $\mathrm{Cu}$ and $\mathrm{Fe}$ and renal $\mathrm{K}$ did not appear to respond appreciably.
\end{abstract}

Minerals: Zinc deficiency: Guinea-pigs

Zinc deficiency in man and domestic animals has been reported throughout the world. There have been a number of studies on $\mathrm{Zn}$ deficiency in laboratory animals, but limited information is available on the interaction of $\mathrm{Zn}$ with other elements during $\mathrm{Zn}$ deficiency ((US) National Research Council, 1979). Most of the studies conducted on $\mathrm{Zn}$ interactions are related to high dietary $\mathrm{Zn}$ levels with copper and iron only. Recently, an interaction of $\mathrm{Zn}$ with sodium and potassium in the brain of $\mathrm{Zn}$-deficient $(\mathrm{ZnD})$ rats has been described (Wallwork et al. 1983). The object of the present investigation was, therefore, to study the serum and tissue levels of $\mathrm{Na}, \mathrm{K}, \mathrm{Cu}$ and $\mathrm{Fe}$ in experimental $\mathrm{ZnD}$ and $\mathrm{Zn}$-repleted $(\mathrm{ZnR})$ guinea-pigs.

\section{MATERIALS AND METHODS}

Experimental studies on $\mathrm{Zn}$ deficiency were conducted using two groups of individually housed, male albino guinea-pigs, aged $21 \mathrm{~d}$. The first group (nineteen animals) received a $\mathrm{ZnD}$ diet $(1.25 \mathrm{mg} \mathrm{Zn} / \mathrm{kg}$ ) and the second group (fourteen animals) a diet adequate in $\mathrm{Zn}$ $(50 \mathrm{mg} \mathrm{Zn} / \mathrm{kg}$ ). The first group was divided into two subgroups, one of ten animals which received the $\mathrm{ZnD}$ diet throughout and another of nine animals which received a $\mathrm{ZnR}$ diet $(100 \mathrm{mg} \mathrm{Zn} / \mathrm{kg})$ after $45 \mathrm{~d}$. Details of the animals used and treatments given have already been described (Gupta et al. 1985). The results presented here were obtained from the same animals.

Blood samples were taken from the heart at the start of the experiment, and thereafter at 12-d intervals, and placed in sterilized tubes for serum separation. On day 60, all animals were killed and the liver, kidney and testis were removed, weighed and stored at $-20^{\circ}$ until required for analysis. $\mathrm{Zn}, \mathrm{Cu}$ and $\mathrm{Fe}$ concentrations in serum and tissues were determined by atomic absorption spectrophotometry after wet ashing with a perchloric-nitric acid mixture (Horwitz, 1965), and $\mathrm{Na}$ and $\mathrm{K}$ by flame photometry (Wootton, 1974).

* For reprints. 
The results of serum analysis were subjected to a two-way analysis of variance, variation being apportioned to treatment and time intervals, and those of tissues to one-way analysis of variance for treatments (Snedecor \& Cochran, 1967). Individual means were compared for statistical significance using least significant difference.

\section{RESULTS \\ Food intake}

Mean food intakes for the animals in each experimental group are shown in Fig. 1. No significant difference was observed in the values in any of the groups.

\section{Clinical signs}

Appearance of clinical signs in guinea-pigs given a $\mathrm{ZnD}$ diet has been reported earlier (Gupta et al. 1985).

\section{Serum studies}

$\mathrm{Zn}$ concentration. Mean serum $\mathrm{Zn}$ concentrations of each group are given in Fig. 2. An overall significant decrease $(P<0.01)$ in serum $\mathrm{Zn}$ concentration was observed in the $\mathrm{ZnD}$ group compared with the control group. The interaction between treatments and time intervals was found to be significant $(P<0 \cdot 01)$. The significant difference between the groups was observed from day 24 onwards. The group given the $\mathrm{ZnR}$ diet showed a rapid increase in serum $\mathrm{Zn}$ concentration within $3 \mathrm{~d}$ of repletion.

$\mathrm{Na}$ concentration. Mean serum Na concentrations for each group are given in Fig. $3(a)$. Overall, serum $\mathrm{Na}$ concentration of the $\mathrm{ZnD}$ group was significantly $(P<0.01)$ lower than that of the control group. The interaction between treatment and time intervals was significantly different $(P<0.05)$ from day 24 . The $\mathrm{Na}$ concentration in the $\mathrm{ZnR}$ group returned almost to that of the control group within $3 \mathrm{~d}$ of $\mathrm{Zn}$ repletion.

$K$ concentration. Mean serum K concentrations for each group are presented in Fig. 3(b). There was an overall significant $(P<0.01)$ increase in $\mathrm{K}$ concentration in the $\mathrm{ZnD}$ group compared with the control group. Interaction between treatment and time intervals was significant $(P<0.01)$ from day 24 onwards. Following $\mathrm{Zn}$ repletion for $15 \mathrm{~d}$, almost complete recovery was noticed in the serum $\mathrm{K}$ values of the $\mathrm{ZnR}$ group compared with values for the $\mathrm{ZnD}$ and control groups.

$\mathrm{Cu}$ concentration. Mean serum $\mathrm{Cu}$ concentrations for each group are given in Fig. 3(c). Though there was a significant $(P<0.05)$ increase overall in the serum $\mathrm{Cu}$ concentration in the $\mathrm{ZnD}$ group compared with the control group, the interaction with time interval was not significant. However, when mean values at different time intervals were compared, a significant increase $(P<0.05)$ in $\mathrm{Cu}$ level of the $\mathrm{ZnD}$ group was observed on day 60 only. The guinea-pigs of the $\mathrm{ZnR}$ group showed a marked recovery in $\mathrm{Cu}$ levels when compared with the corresponding control value on day 15 of $\mathrm{Zn}$ repletion.

$\mathrm{Fe}$ concentration. Mean Fe concentrations for each experimental group are shown in Fig. $3(d)$. A significant increase $(P<0.01)$ in Fe concentration was observed in the $\mathrm{ZnD}$ group compared with the control group from day 36 onwards. Following $15 \mathrm{~d}$ of $\mathrm{Zn}$ repletion, guinea-pigs exhibited a marked change in serum Fe concentration.

\section{Tissue studies}

The average weights of liver, kidney and testis along with the mean values of $\mathrm{Zn}, \mathrm{Na}, \mathrm{K}$, $\mathrm{Cu}$ and $\mathrm{Fe}$ are given in Table 1. While a significant difference $(P<0.01)$ among the experimental groups was observed only in the absolute weight of testis, there was no significant difference in weights of the tissues when expressed as a proportion of the bodyweight. 


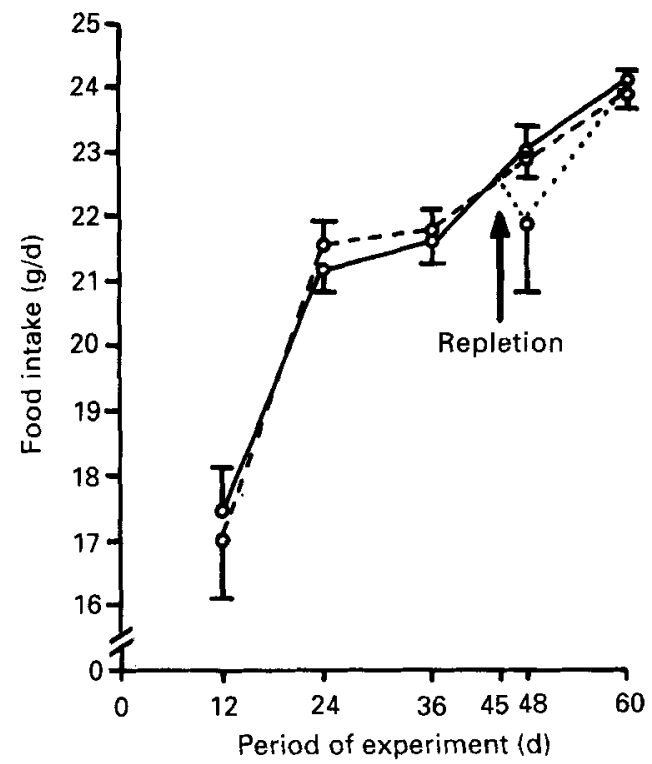

Fig. 1. Feed intake of zinc-deficient (---), Zn-repleted (...) and control ( $\longrightarrow$ guinea-pigs. Values are means with their standard errors represented by vertical bars. For details of treatments, see Gupta et al. (1985).

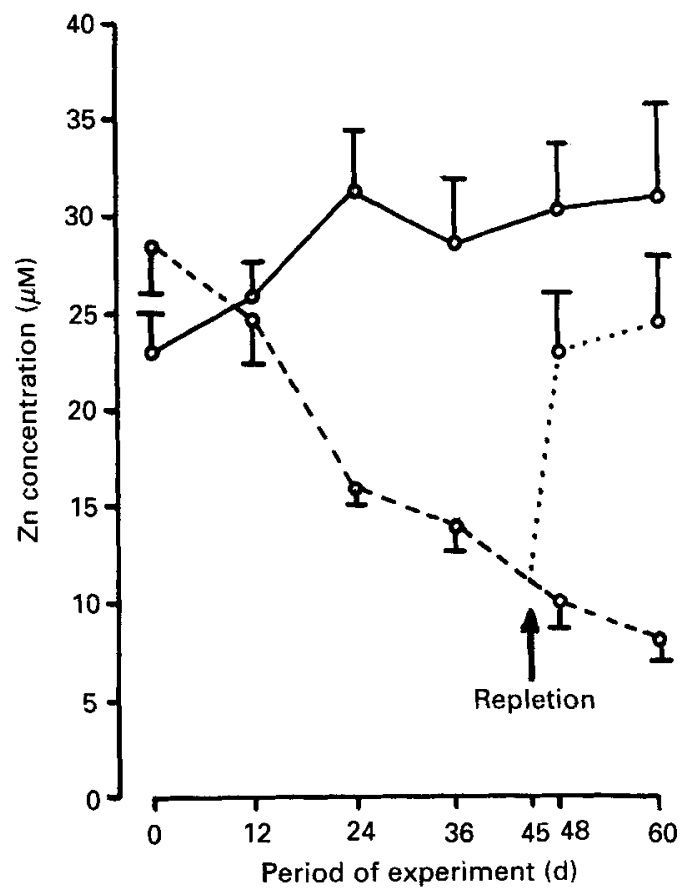

Fig. 2. Serum zinc concentration $(\mu \mathrm{M})$ of $\mathrm{Zn}$-deficient $(---)$, Zn-repleted (...) and control (- $)$ guinea-pigs. Values are means with their standard errors represented by vertical bars. For details of treatments, see Gupta et al. (1985). 

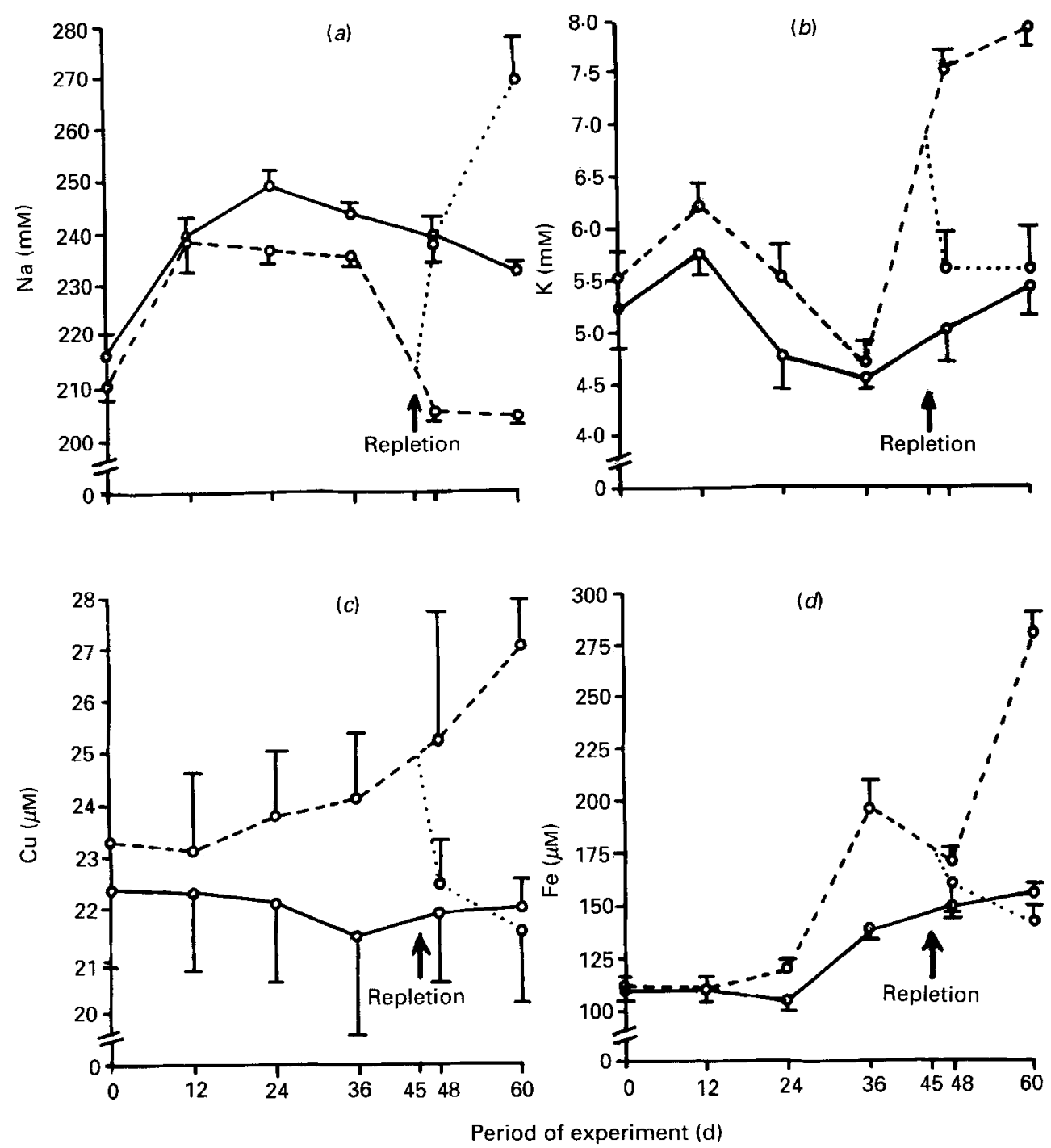

Fig, 3. Serum concentrations of sodium $(a)$, potassium $(b)$, copper $(c)$ and iron $(d)$ in zinc-deficient $(---)$, $\mathrm{Zn-}$ repleted $(. .$.$) and control (-)$ guinea-pigs. Values are means with their standard errors represented by vertical bars. For details of treatments, see Gupta et al. (1985).

Significant decreases in Na concentrations of liver and kidney were observed in the $\mathrm{ZnD}$ group when compared with the controls. In the ZnR group, a marked improvement in $\mathrm{Na}$ concentration was noticed within $15 \mathrm{~d}$ of repletion. Significantly $(P<0.01)$ lowered values of $\mathrm{K}$ contents were observed only in kidney and testis of the $\mathrm{ZnD}$ group when compared with the control group. The guinea-pigs of the $\mathrm{ZnR}$ group showed a rapid increase in the $\mathrm{K}$ content of testis only following $\mathrm{Zn}$ repletion. Although the $\mathrm{Cu}$ contents in liver, kidney and testis of the $\mathrm{ZnD}$ group were higher than those of the control group, the differences were significant $(P<0.01)$ only for the liver and kidney. After $15 \mathrm{~d}$ of $\mathrm{Zn}$ repletion, decreases in $\mathrm{Cu}$ content of these tissues were observed but $\mathrm{Cu}$ concentration in liver was still significantly higher $(P<0.01)$ in comparison with that of the controls. Hepatic and renal Fe concentrations in the $\mathrm{ZnD}$ group were found to have increased $(P<0.01)$, whereas 


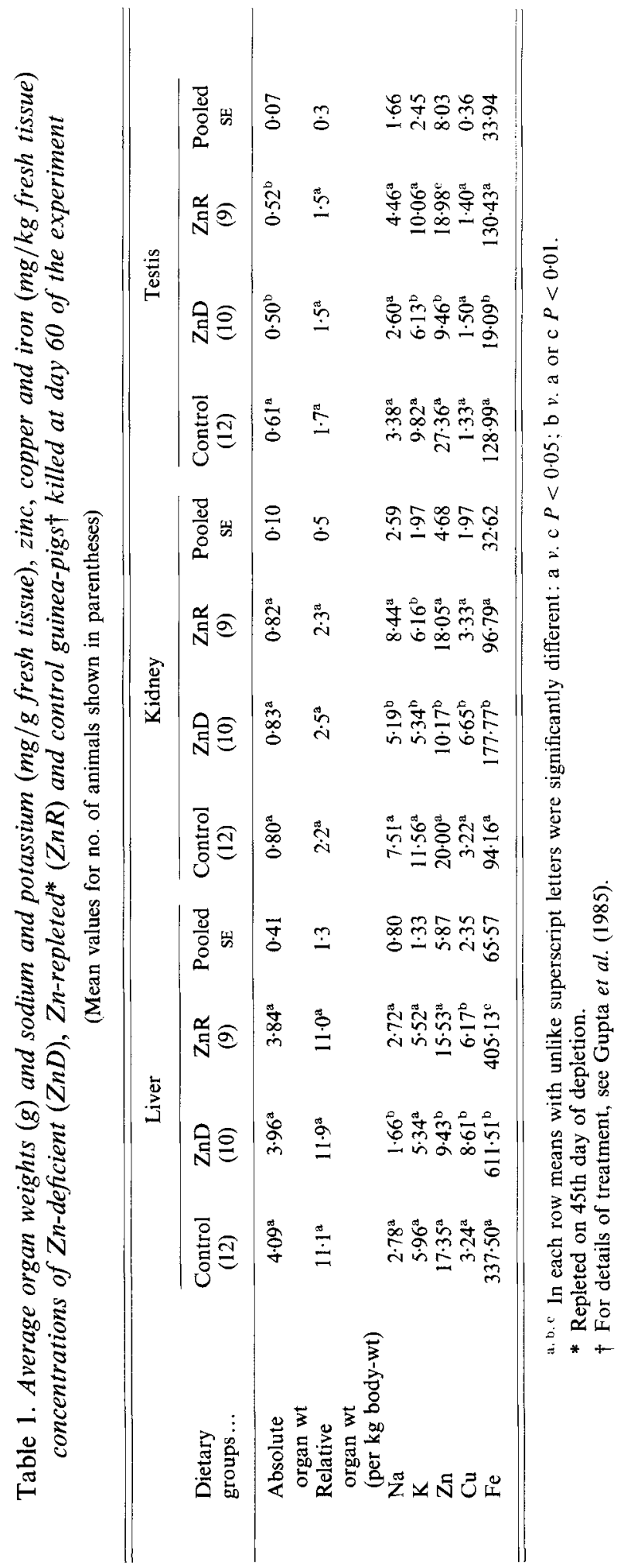


in the testis Fe concentration decreased significantly $(P<0.01)$. The differences in Fe values of the kidney and testis between the $\mathrm{ZnR}$ and control groups were not significant, but hepatic Fe concentration in the $\mathrm{ZnR}$ group was still higher, although at a lower level of significance $(P<0.05)$, indicating slight improvement.

\section{DISCUSSION}

The functional roles (growth, bone formation, brain development, reproduction, immune mechanism, membrane stability and wound healing) of $\mathrm{Zn}$ are fairly well understood (Nariagu, 1980), but its interaction with other elements when in the deficient state is not well-documented. Anorexia is generally accepted as inevitable during $\mathrm{Zn}$ deficiency and pair-feeding with $\mathrm{Zn}$-adequate controls is considered desirable. However, in the present study food intakes by the animals in different groups were almost identical. Similarly, Mc Bean et al. (1972) and Gordon \& O'Dell (1983) did not notice any effect of Zn deficiency on food intake in guinea-pigs. Thus the results reported in the present study suggest that the primary cause of the alterations noticed in the minerals is $\mathrm{Zn}$ deficiency per se unaccompanied by reduced food intake.

There was a significant decrease in the serum $\mathrm{Na}$ concentration of the $\mathrm{ZnD}$ group from day 24 onwards. A significant decrease in $\mathrm{Na}$ concentration was also noticed in liver and kidney. The decrease in serum $\mathrm{Na}$ concentrations was parallel to the serum $\mathrm{Zn}$ levels which were also significantly lower from day 24 onwards. The only report (Wallwork et al. 1983) traced in the literature also revealed a decrease in $\mathrm{Na}$ concentration in the brain of $\mathrm{ZnD}$ rats. The mechanism involved in $\mathrm{Na}$ depletion during experimental $\mathrm{Zn}$ deficiency has to be investigated. However, medullary hyperplasia and atrophy of zona glomerulosa as observed in the adrenal glands of $\mathrm{ZnD}$ guinea-pigs (Gupta et al. 1988) and angiotensin II deficiency (Reeves \& O'Dell, 1986) might have contributed to hyponatraemia, since these changes have been reported to impair $\mathrm{Na}$ re-absorption from renal tubules due to impairment of synthesis and secretion of mineral corticoids (Duncan et al. 1951; Forbes, 1962; Jubb et al. 1985).

Serum $\mathrm{K}$ concentration in the $\mathrm{ZnD}$ group increased significantly from day 48 onwards. This was accompanied by a decrease in its concentration in kidney and testis. Widdowson \& Dickerson (1964) reported a decrease in the K content of the testis during its atrophy and degeneration, a consistent feature of $\mathrm{Zn}$ deficiency. Moreover, an increase in catecholamine secretion (Wallwork et al. 1982) or adrenal medullary hyperplasia (Gupta et al. 1988) observed during $\mathrm{Zn}$ deficiency might have caused liberation of $\mathrm{K}$ from tissues (D'Silva, 1937; Todd \& Vick, 1971 ; Kaufman \& Papper, 1983) into the plasma, thus leading to a fall in the $\mathrm{K}$ level of tissues. This release of intracellular $\mathrm{K}$ into the circulation might be one of the important factors in the hyperkalaemia observed in $\mathrm{ZnD}$ guinea-pigs. Atrophy of the zona glomerulosa of the adrenal cortex, as observed in $\mathrm{ZnD}$ guinea-pigs (Gupta et al. 1988), might also have contributed to hyperkalaemia since hypoaldosteronism has been reported to impair renal tubular $\mathrm{K}$ secretion resulting in a rise in serum $\mathrm{K}$ levels (Kaufman \& Papper, 1983; Jubb et al. 1985).

Serum $\mathrm{Cu}$ in the present study increased in the $\mathrm{ZnD}$ group within $24 \mathrm{~d}$ of the experiment, but the increase was statistically significant $(P<0.05)$ on day 60 only. Concurrently, there were appreciable increases in the $\mathrm{Cu}$ contents of liver and kidney. A similar inverse interrelation between $\mathrm{Zn}$ and $\mathrm{Cu}$ has also been reported in rats (Murthy et al. 1974; Burch et al. 1975; Roth \& Kirchgessner, 1977; Kirchgessner et al. 1979). This may be due to an increase in $\mathrm{Cu}$ absorption (Schwarz \& Kirchgessner, 1974) or Cu-binding proteins (Bremner \& Marshall, 1974a, $b$ ), or a decrease in faecal and urinary Cu excretion (Gandhi, 1982). Moreover, Speckhard et al. (1977) reported the replacement of intrinsic Zn ions of 
E. coli RNA polymerase with $\mathrm{Cu}$ in vivo in a low- $\mathrm{Zn}$ medium without alteration in cell morphology, growth rate and yield. Hypothyroidism and thyroid atrophy, as observed in Zn deficiency by Morley et al. (1980) in rats and Gupta et al. (1988) in guinea-pigs, might also have contributed to the increase in hepatic and serum $\mathrm{Cu}$ contents since Gubler et al. (1952) and Evans et al. (1970) reported that in rats, thyroid insufficiency resulted in accumulation of hepatic $\mathrm{Cu}$ because of decreased biliary $\mathrm{Cu}$ excretion, a major pathway for hepatic $\mathrm{Cu}$ removal.

The significant increase in serum, liver and kidney Fe concentration observed in the $\mathrm{ZnD}$ group in the present study has also been documented in rats (Roth \& Kirchgessner, 1977; Reinstein et al. 1984). The mechanism underlying the effect of $\mathrm{Zn}$ on Fe metabolism during $\mathrm{Zn}$ deficiency is not known. O'Nell-Cutting et al. (1981) reported that the mechanism by which high levels of dietary $\mathrm{Zn}$ resulted in depletion of hepatic $\mathrm{Fe}$ stores remains unexplained, since they found no interference of $\mathrm{Zn}$ with either intestinal Fe absorption or with cellular uptake of $\mathrm{Fe}$ from circulating transferrin and storage as ferritin.

$\mathrm{Zn}$ repletion to previously $\mathrm{ZnD}$ guinea-pigs resulted in a rapid improvement in serum and tissue concentrations of the previously mentioned minerals within $15 \mathrm{~d}$. However, hepatic $\mathrm{Cu}$ and $\mathrm{Fe}$ and renal $\mathrm{K}$ did not appear to respond appreciably.

\section{REFEREN CES}

Bremner, I. \& Marshall, R. B. (1974a). Hepatic copper- and zinc-binding proteins in ruminants. 1. Distribution of $\mathrm{Cu}$ and $\mathrm{Zn}$ among soluble proteins of livers of varying $\mathrm{Cu}$ and $\mathrm{Zn}$ content. British Journal of Nutrition 32, 283-291.

Bremner, I. \& Marshall, R. B. (1974b). Hepatic copper- and zinc-binding proteins in ruminants. 2. Relationship between $\mathrm{Cu}$ and $\mathrm{Zn}$ concentrations and the occurrence of a metallothionein-like fraction. British Journal of Nutrition 32, 293-300.

Burch, R. E., Williams, R. V., Hahn, H. K. J., Jetton, M. M. \& Sullivan, J. F. (1975). Serum and tissue enzyme activity and trace element content in response to zinc deficiency in pig. Clinical Chemistry 21, 568-577.

D'Silva, J. L. (1937). Action of adrenaline on the serum potassium. Journal of Physiology 90, 303-310.

Duncan, L. E. Jr, Solomon, D. H., Nichols, M. P. \& Rosenberg, E. (1951). The effect of the chronic administration of adrenal medullary hormones to man on adreno-cortical functions and the renal excretion of electrolytes. Journal of Clinical Investigation 30, 908-914.

Evans, G. W., Cornatzer, N. F. \& Cornatzer, W. E. (1970). Mechanism for hormone-induced alterations in serum ceruloplasmin. American Journal of Physiology 218, 613-615.

Forbes, G. B. (1962). Sodium. In Mineral Metabolism, vol. 2, part B, pp. 2-72 [C. L. Comar and F. Bronner, editors]. New York: Academic Press.

Gandhi, S. (1982). Effect of different levels of zinc on the availability of iron and copper. MSc Thesis, Haryana Agricultural University, Hisar, India.

Gordon, P. R. \& O'Dell, B. L. (1983). Zinc deficiency and impaired platelet aggregation in guinea-pigs. Journal of Nutrition 113, 239-245.

Gubler, C. L., Lahey, M. E., Cartwright, G. E. \& Wintrobe, M. M. (1952). Studies on copper metabolism. XFactors influencing the plasma copper level of the albino rat. American Journal of Physiology 171, $652-658$.

Gupta, R. P., Verma, P. C. \& Gupta, R. K. P. (1985). Experimental zinc deficiency in guinea-pigs: clinical signs and some haematological studies. British Journal of Nutrition 54, 421-428.

Gupta, R. P., Verma, P. C., Sadana, J. R. \& Gupta, R. K. P. (1988). Studies on the pathology of experimental zinc deficiency in guinea-pigs. Journal of Comparative Pathology 98, 405-413.

Horwitz, W. (1965). Official Methods of Analysis of the Association of Official Analytical Chemists, p. 193. Washington, DC: Ben Franklin Press.

Jubb, K. V. F., Kennedy, P. C. \& Palmer, N. (1985). Pathology of Domestic Animals, vol. 3, pp. 282-294. New York: Academic Press.

Kaufman, C. E. \& Papper, S. (1983). Hyperkalemia. In Potassitum: its Biological Significance, pp. 77-96 [R. Whang, editor]. Boca Raton, Florida: CRC Press.

Kirchgessner, M., Schwarz, F. J., Grassman, E. \& Steinhart, H. (1979). Interactions of copper with other trace elements. In Copper in the Environment, part 2, Health Effects, pp. 442-448 [J. O. Nariagu, editor]. New York John Wiley \& Sons.

McBean, L. D., Smith, J. C. Jr \& Halsted, J. A. (1972). Zinc deficiency in guinea-pigs. Proceedings of the Society for Experimental Medicine 140, 1207-1209. 
Morley, J. E., Gordon, J. \& Hershman, J. M. (1980). Zinc deficiency, chronic starvation and hypothalemic-pituitary-thyroid function. American Journal of Clinical Nutrition 33, 1767-1770.

Murthy, L., Klevay, L. M. \& Petering, H. G. (1974). Interrelationship of zinc and copper nutriture in the rats. Journal of Nutrition 104, 1458-1465.

Nariagu, J. O. (1980). Zinc in the Environment, part 2, Health Effects. New York: John Wiley \& Sons.

National Research Council (1979). Zinc, pp. 183-189. Baltimore: University Park Press.

O'Nell-Cutting, M. A., Bomford, A. \& Munro, H. N. (1981). Effect of excess dietary zinc on tissue storage of iron in rats. Journal of Nutrition 111, 1969-1979.

Reeves, P. G. \& O'Dell, B. L. (1986). Effects of dietary zine deprivation on the activity of angiotensin-converting enzyme in serum of rats and guinea-pigs. Journal of Nutrition 116, 128-134.

Reinstein, N. H., Lonnerdal, B., Keen, C. L. \& Hurley, L. S. (1984). Zinc-copper interactions in the pregnant rat: field outcome and maternal and fetal zinc, copper and iron. Journal of Nutrition 114, 1266-1279.

Roth, H. P. \& Kirchgessner, M. (1077). Contents of zinc, copper, iron, manganese and calcium in bones and livers of rats depleted and refed with zinc. Zentrablatt für Veterinärmedizin 24A, 177-188.

Schwarz, F. J. \& Kirchgessner, M. (1974). Intestinal absorption of copper, zinc and iron after dietary depletion. In Trace Element Metabolism in Animals, vol. 2, pp. 519-522 [W. G. Hoekstra, J. W. Suttle, H. E. Ganther and W. Mertz, editors]. Baltimore: University Park Press.

Snedecor, G. W. \& Cochran, W. G. (1967). Statistical Methods. Ames, Iowa: Iowa State University Press.

Speckhard, D. C., Wu, F. Y. H. \& Wu, C. W. (1977). Role of the intrinsic metal in RNA polymerase from Escherichia coli. In vivo substitution of tightly bound zinc with cobalt. Biochemistry 16, 5228-5233.

Todd, E. P. \& Vick, R. L. (1971). Kalemotropic effect of epinephrine. American Journal of Physiology 220 , $1964-1969$.

Wallwork, J. C., Bothen, J. H. \& Sandstead, H. H. (1982). Influence of dietary zinc on rat brain catecholamines. Journal of Nutrition 112, 514-519.

Wallwork, J. C., Milne, D. B., Sims, R. L. \& Sandstead, H. H. (1983). Severe zinc deficiency: effects on the distribution of nine elements (potassium, sodium, magnesium, calcium, iron, zinc, copper and manganese) in regions of the rat brain. Journal of Nutrition 113, 1895-1905.

Widdowson, M. E. \& Dickerson, J. W. T. (1964). Chemical composition of the body. In Mineral Metabolism, vol. 2, part A, pp. 146-171 [C. L. Comar and F. Bronners, editors]. New York: Academic Press.

Wootton, I. D. P. (1974). Microanalysis in Medical Biochemistry. London: J. A. Churchill Livingstone. 